\title{
OUTSOURCING AND OFFSHORING OF BUSINESS SERVICES: HOW IMPORTANT IS ICT?
}

\author{
Laura Abramovsky \\ Institute for Fiscal Studies
}

\author{
Rachel Griffith \\ Institute for Fiscal Studies
}

\begin{abstract}
This paper considers the impact that information and communication technology (ICT) has on firms' choices over organisational form. In particular, the decision over whether to produce in-house or outsource services, and the decision over the location of activity. ICT reduces the transaction and adjustment costs of moving activity outside the firm, and of carrying it out at greater geographic distance. We find that more ICT-intensive firms purchase a greater amount of services on the market and they are more likely to purchase offshore than less ICT-intensive firms. (JEL: D21, F23, L23)
\end{abstract}

\section{Introduction}

Greater competitive pressures and rapidly changing technologies mean that small and adaptable firms are increasingly favoured by the market. ${ }^{1}$ General purpose technologies such as information and communication technology (ICT) increase the adaptability and compatibility of many services with the needs of the purchasers of these services. Technological advances have facilitated the tradability of services, both within and across firms and national borders. ${ }^{2}$ Taken together these mean that firms face increasing benefits from outsourcing business services.

In this paper we consider whether ICT investment is an important factor driving outsourcing and offshoring decisions. We consider the outsourcing and

Acknowledgments: This work was funded by the ESRC/EPSRC AIM initiative and the IFS. We are grateful to Richard Blundell, Rupert Harrison, Mari Sako, Helen Simpson, Abigail Tierney, an anonymous referee, and participants at a workshop at Said Business School for useful comments. This work contains statistical data from ONS which is Crown Copyright and reproduced with the permission of the controller of HMSO and Queen's Printer for Scotland. The use of the ONS statistical data in this work does not imply the endorsement of the ONS in relation to the interpretation or analysis of the statistical data. Responsibility for any results, opinions, and errors lies with the authors alone.

E-mail addresses: Abramovsky: laura_a@ifs.org.uk; Griffith: rgriffith@ifs.org.uk

1. See, for instance, Milgrom and Roberts (1990), Athey and Schmutzler (1995), and Marin and Verdier (2003).

2. See, for instance, Feenstra (1998), Grossman and Helpman (2005), and Antras (2003).

Journal of the European Economic Association April-May 2006 4(2-3):594-601

(C) 2006 by the European Economic Association 


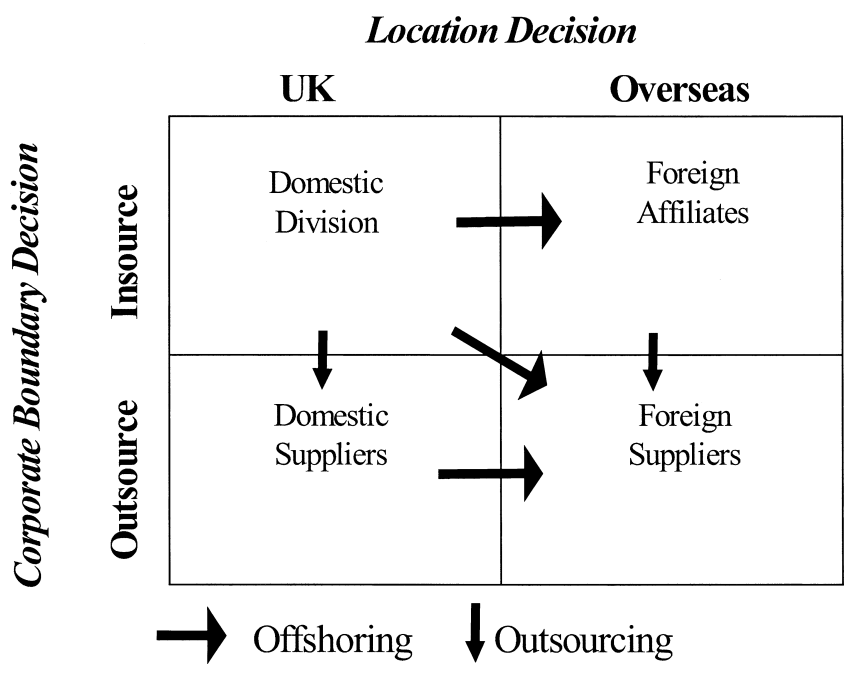

FIGURE 1. Outsourcing and offshoring.

offshoring decisions in the context of firms' productive behaviour, and estimate the impact of ICT using a large and nationally representative data set at the establishment level. We consider how variation in ICT investment across firms within an industry affects the level of outsourcing and offshoring services.

Figure 1 illustrates what we mean by outsourcing and offshoring. Outsourcing is the decision to make or buy, regardless of where the activity takes place (denoted by the vertical arrows). Offshoring is about where the activity takes place, regardless of whether it is within the corporate boundary or outside it (denoted by the horizontal arrows).

The empirical literature on outsourcing has largely focused on specific industries, and exploited variation in firm characteristics. ${ }^{3}$ Recently, several papers have considered industry characteristics as determinants of organizational form. ${ }^{4}$ Both strands of the literature focus mainly in outsourcing of materials. However, one of the most substantial changes in economic activity over recent years has been the substantial growth in the outsourcing of business services. ${ }^{5}$

The structure of this paper is as follows. In Section 2 we discuss the firm's outsourcing and offshoring decisions in the context of firm production behaviour and our empirical specification. In Section 3 we discuss our data and in Section 4 present our results. Section 5 concludes.

3. See survey in Klein (2005) and a recent example in Baker and Hubbard (2002).

4. See, inter alia, Antras (2003) and Acemoglu et al. (2004).

5. See, inter alia, Abramovsky, Griffith, and Sako (2004) and Goodman and Steadman (2002). 


\section{Theory and Empirical Specification}

We think about a firm's decision to outsource and offshore services as depending on the firm's ICT intensity, which varies within industries. ${ }^{6}$ Firms are costminimising. Demand for outsourced services depends on the relative cost of producing the services in-house compared to outsourcing, which varies across firms according to the firm's investment in ICT. The result is that some firms outsource more than others. $^{7}$

We assume that the demand for business services $S$ by a firm in an industry is a fixed proportion of the total output produced by the firm, namely, $S=\alpha Y$. This implies that business services are a perfect complement of the firms' main activities and, hence, that demand for business services does not depend on the prices of inputs used to produce the firm's main product. The assumption of fixed proportions seems reasonable for business services, many of which are ancillary to the firms main activities (for example, accounting, recruitment, and legal services). Our interest is in how past ICT investments affect the firm's decision over whether to purchase these services on the market, versus make in-house. Total business services are made up of in-house services $\left(S_{1}\right)$ and outsourced services $\left(S_{2}\right)$. A cost-minimising firm will choose $S_{1}$ and $S_{2}$ such that it minimizes the cost of $S$. Denote the unit cost of producing each of these as $c_{1}$ and $c_{2}$ respectively. The expenditure share of outsourced services will be a function of these relative costs and the firm's output.

What is the nature of the costs $c_{1}$ and $c_{2}$ ? These may differ from each other and across firms. The cost of producing in-house will depend on factors such as the productivity level, age, and size of the firm. We assume that the cost of outsourcing is given by $c_{2 i}=p_{2} u_{i}$, where $p_{2 i}$ is the market price of the service and $u_{i} \geq 0$ is a firm-specific cost of outsourcing, which will reflect: (a) adjustment costs: a service produced by a third party may only imperfectly match the purchasers' needs compared to an in-house service that is perfectly customized; (b) transaction costs: given asset specificity and incomplete contracts $u_{i}$ there is a cost to the market transaction; ${ }^{8}$ (d) the costs of monitoring and writing contracts mediated by the market; and finally, search costs for finding the best supplier (see Grossman and Helpman 2005). ${ }^{9}$

We don't observe $c_{1}$ or $c_{2}$. We conjecture that a firm's ICT investment decreases $u_{i}$ by more than it decreases $c_{1 i}$. ICT is characterised by its compatibility

6. Recent work on modelling outsourcing and offshoring decisions has focused on the role of technology in affecting the cost of outsourcing. See, inter alia, Grossman and Helpman $(2002,2005)$ and Antras and Helpman (2004).

7. See Marin and Verdier (2005), Antras and Helpman (2004) and Bartel, Lach, and Sicherman (2005) for studies that look at within industry determinants of organizational form.

8. See, for instance, Williamson (1996) and Hart (1995). Also, see Joskow (2005) for a review.

9. See Grossman and Helpman (2005). 
with general skills, which can be transferred easily across firms, and so decreases the degree of specificity of the transaction. ICT is also expected to reduce directly the transaction and search costs. Hence, we expect that firms that have invested more heavily in ICT will have a lower relative cost of outsourced services and a greater expenditure in outsourcing services. We assume that the relative price of services, $p_{1 i} / p_{2 i}$, is constant across firms within narrowly defined industries and so is captured by industry fixed effects.

From this we derived our empirical specification as

$$
\ln \left(\frac{c_{2 i} S_{2}}{p Y}\right)_{i}=\mu_{j}+\beta \ln (i c t)_{i}+\varepsilon_{i}
$$

We are also interested in the location decision. Conditional on outsourcing, does the firm purchase from abroad and how does ICT affect this decision? We consider this as a discrete decision and estimate the probability that a firm purchases from abroad using a probit model. Analogous to the discussion above, we expect ICT to be also important for search, transaction, and adjustment costs of importing services.

\section{Data}

We use establishment (line of business) level data from the ABI-ARD. This contains information on the bulk of economic activity located in the UK and is collected by the Office of National Statistics. ${ }^{10}$ Response is mandatory. Information on inputs and output is collected from a random stratified sample of firms at the line of business (4-digit industry) level. We use data on all private sector establishments for the years 2001 and 2002. ${ }^{11}$

Firms are asked to report expenditure on a number of specific services which can be produced in-house or purchased on the market. These include road transport services, telecommunications, computer services, professional and surveyors services, legal services, payments to employment agencies, and hiring of plant and machinery. We use these purchases as a measure of outsourcing of business services. ${ }^{12}$ Firms are also asked to report total expenditure on imported services.

We measure an establishment's ICT intensity using data on: (i) investment in software, and (ii) whether they use the Internet to order goods or services. Investment in software includes investment in purchased computer software and

10. See Barnes and Martin (2002) and Griffith (1999) for a description of the data. Agriculture and the financial sector are not included.

11. These are currently the only years when ICT investment is available.

12. Firms can purchase services from themselves (insourcing). We checked how important this was by looking at some specific services where we could identify the industry they were produced in. We then looked at whether the firm was also a producer of the purchased product. This was only the case in a very small proportion of firms, so we do not believe that this is driving our results. 
TABLE 1. Descriptive statistics; technology, purchase, and import of services.

\begin{tabular}{lc}
\hline Variable & Mean \\
\hline Proportion of establishments that do any ICT investment (\%) & 62 \\
Average ICT/Y & 0.003 \\
Proportion of establishments that use internet to order goods or services (\%) & 30.8 \\
Average purchased services as a share of output (\%) & 13 \\
Proportion of establishments importing any services (\%) & 6.5 \\
Average age & 9 \\
Average number of employees in the firm & 753 \\
Proportion of foreign-owned establishments (\%) & 11 \\
Number of observations & 51,225 \\
\hline
\end{tabular}

Source: Authors' calculations using ONS data. All statistical results remain Crown Copyright.

in computer software developed by the establishment's own staff. We scale this by total output of the establishment. ${ }^{13}$

Table 1 shows descriptive statistics of the proportion of firms that invest in ICT, the intensity of investment, and how many firms use the Internet to order goods or services. It also shows some descriptive statistics on purchases and imports of business services. Business services represent around $13 \%$ of total output (though there is substantial variation between industries and even more within industries, not shown). Around $6.5 \%$ of firms import some business services (these account for around $1 \%$ of total services). These also vary substantially both across sectors and across firms. The table also shows some further descriptive statistics of firm and estatablishment characteristics.

\section{Empirical Results}

\subsection{Outsourcing}

We start by looking at the outsourcing decision and estimating equation (1). The main coefficients of interest in Table 2 are those on ICT and use of Internet. ${ }^{14}$ In the first column we include an indicator of whether an establishment uses the Internet. The estimate suggests that establishments that use the Internet outsource about $10.6 \%$ more that those that do not. A major concern is with the endogeneity of the ICT variables. Firms that anticipate outsourcing may invest more in ICT. We use two forms of exogenous variation in the price of ICT and using the Internet, which will give us independent variation in these variables. These are a tax credit that the UK government introduced in 2000 for small firms investments in ICT,

13. This measure of ICT investment is partial, because it does not include, for example, investment in hardware. We assume that investment in software is a constant proportion of total investment in $\operatorname{ICT},(\widetilde{i c t / y})=\varphi_{\tilde{j}}(i c t / y)$, so that $\varphi_{\tilde{j}}$ is captured by industry fixed effects.

14. The results in Table 2 indicate that older firms, foreign-owned firms, and larger firms outsource more. 
TABLE 2. Determinants of amount of services outsourced (dependent variable: $\ln (\operatorname{serv} / y))$.

\begin{tabular}{lcccc}
\hline & $(1)$ & $(2)$ & $(3)$ & $(4)$ \\
& OLS & IV & OLS & IV \\
\hline Use Internet & 0.106 & 2.020 & & \\
& $(0.008)$ & $(0.165)$ & & \\
Tech (ICT + use Internet) & & & 0.135 & 1.389 \\
& & & $(0.006)$ & $(0.077)$ \\
Age & 0.002 & -0.001 & 0.001 & -0.002 \\
& $(0.001)$ & $(0.001)$ & $(0.001)$ & $(0.001)$ \\
Foreign-owned & 0.160 & 0.024 & 0.157 & 0.054 \\
& $(0.013)$ & $(0.023)$ & $(0.013)$ & $(0.014)$ \\
Firm emp in 1,000s & 0.004 & -0.011 & 0.004 & -0.006 \\
& $(0.001)$ & $(0.002)$ & $(0.001)$ & $(0.001)$ \\
Partial $R 2 ;$ & & 0.005 & & 0.005 \\
$F$-test $(p$ value) & & $126.21(0.000)$ & & $122.5(0.000)$ \\
Hansen test & & 0.948 & & 1.481 \\
$(p$ value $)$ & & $(0.330)$ & & $(0.224)$ \\
\hline
\end{tabular}

Note: The data contain 51,225 observations for 2001 and 2002. All regressions include establishment age, number of employees in the firm, whether the firm is foreign-owned, region, industry (3-digit), and time dummies. Robust standard errors in parentheses. Partial $R 2$ is an indicator of the power of the instruments, it is the partial $R 2$ of the excluded variables in the first stage regression. $F$-tests is a test of the joint significance of the excluded instruments. Hansen test is an overidentification test of all instruments. Source: Authors' calculations using ONS data. All statistical results remain Crown Copyright.

and regional variation in Internet infrastructure, measured by the proportion of households with home access to the Internet. We use the discontinuity in eligiblity for the tax credit—only firms with fewer than 250 employees were eligibleto identify this from a firm size effect. Column 2 shows the results when we instrument Internet usage. They suggest that the OLS coefficients are downward biased. This is somewhat puzzling, as we would expect upward bias, but may reflect measurement error. The tests statistics at the bottom of the table suggest that the instruments are valid, and have some explanatory power, though the low value of the partial $R^{2}$ suggests that the instruments do not have that much explanatory power. The coefficient on the Internet use dummy is an elasticity. It suggests that a $1 \%$ increase in the proportion of firms using the Internet would lead to a $2 \%$ increase in the level of outsourcing.

In column 3 we use the variable tech, which is the sum of ICT and Internet usage (it equals 1 if the firm does either and 2 if it does both), and in column 4 we show the results for instrumenting tech.

\subsection{Offshoring}

We now turn to look at whether ICT affects establishments' decision to purchase business services offshore. Table 3 shows marginal effects from a probit for whether an establishment imports any business services. In column 1 we include an indicator of whether the establishment uses the Internet to order goods or services. We see that using the Internet increases the probablity of purchasing 
TABLE 3. Determinants of whether import any services or not (dependent variable: import any services or not).

\begin{tabular}{lcccc}
\hline & $(1)$ & $(2)$ & $(3)$ & $(4)$ \\
& Probit & $\mathrm{CF}$ & Probit & CF \\
\hline Use Internet & 0.021 & 0.120 & & \\
& $(0.002)$ & $(0.049)$ & & \\
Tech (ICT + use Internet) & & & 0.027 & 0.061 \\
& & & $(0.001)$ & $(0.018)$ \\
CF use of Internet & & 0.070 & & \\
CF tech & & & \\
& & & & -0.034 \\
Age & 0.000 & 0.000 & 0.000 & $(0.018)$ \\
Foreign-owned & $(0.000)$ & $(0.000)$ & $(0.000)$ & 0.0002 \\
& 0.044 & 0.036 & 0.042 & $.0002)$ \\
pred $p$ at xbar & $(0.004)$ & $(0.005)$ & $(0.004)$ & $(0.004)$ \\
& 0.046 & 0.046 & 0.046 & 0.046 \\
\hline
\end{tabular}

Note: The data contain 50,945 observations for years 2001 and 2002. Marginal effects from probit. Observed $p$ is 0.065 . All regressions include age, firm employment, region, industry (3-digit) and time dummies. Some observations dropped because all in industry either 0/1. Robust standard errors in parentheses. Source: Authors' calculations using ONS data. All statistical results remain Crown Copyright.

offshore by around $2 \%$. To control for endogeneity in column 2 we include a control function, ${ }^{15}$ which again, puzzlingly, indicates negative bias in the OLS estimates. The coefficient increases to $12 \%$. In column 3 we use the variable tech and in column 4 we instrument tech. The results suggests that either investing in ICT or using the Internet increases the probability of a firm offshoring by around $6 \%$, and that doing both increases it by around $12 \%$.

\section{Conclusions}

In this paper we consider how ICT investment affects the cost of outsourcing and offshoring services relative to in-house production. We focus on within industry firm level variation. We show that ICT plays an important role in facilitating firms decisions over both whether to outsource and offshore services.

A concern in European economies has been the slow uptake of $\mathrm{ICT}^{16}$ and how this may impact on productivity growth. ICT investment in the UK is around half of the US level. ${ }^{17}$ Our results here suggest that one important mechanism maybe by holding back the process of fragmentation and specialisation.

15. This entails including the first-stage residuals in the regression equation. In linear models, control function and IV coefficient estimates are identical. See Wooldridge (2002), chapter 18 or Blundell and Powell (2004). Here we have restricted the first stage to a single equation, so it is not the same as IV.

16. See, for instance, van Ark et al. (2001) and Basu et al. (2003).

17. See Oulton and Srinivasan (2005). 


\section{References}

Abramovsky, Laura, Rachel Griffith, and Mari Sako (2004). "Offshoring of Business Services and Its Impact on the UK Economy." IFS Briefing Note BN51, AIM Briefing Note.

Acemoglu, Daron, Philippe Aghion, Rachel Griffith and Fabrizio Zilibotti (2004). "Vertical Integration and Technology: Theory and Evidence." IFS Working Paper, W04/34.

Antras, Pol (2003). "Firms, Contract and Trade Structure." Quarterly Journal of Economics, $118,1375-1418$.

Antras, Pol, and Elhanan Helpman (2004). "Global Sourcing." Journal of Political Economy, $112(3), 552-580$.

Athey, Susan, and Armin Schmutzler (1995). "Product and Process Flexibility in an Innovative Environment." RAND Journal of Economics, 26, 557-574.

Baker, George, and Thomas Hubbard (2002). "Make versus Buy in Trucking: Asset Ownership, Job Design and Information.” NBER Working Paper 8727.

Barnes, Matt, and Martin, Ralf (2002). "Business Data Linking: An Introduction.” Economic Trends, 581, 34-41.

Bartel, Ann, Saul Lach, and Nachum Sicherman (2005). "Outsourcing and Technological Change.” NBER Working Paper 11158.

Basu, Susanto, John Fernald, Nick Oulton, and Sylaja Srinivasan (2003). "The Case of Missing Productivity Growth; Or, Does Information Technology Explain Why Productivity Accelerated in the United States but Not in the United Kingdom?" NBER, Working Paper 10010.

Blundell, Richard, and James L. Powell (2004). "Endogeneity in Semiparametric Binary Response Models." Review of Economic Studies 71, 655-679.

Feenstra, Robert (1998). "Integration of Trade and Disintegration of Production." Journal of Economic Perspective, 12, 31-50.

Goodman, Bill, and Reid Steadman (2002). "Services: Business Demand Rivals Consumer Demand in Driving Job Growth.” Monthly Labor Review, April 2002, 3-16.

Griffith, Rachel (1999). "Using the ARD Establishment-level Data to Look at Foreign Ownership and Productivity in the United Kingdom." Economic Journal, 109, F416-F442.

Grossman, Gene, and Elhanan Helpman (2002). "Integration versus Outsourcing in Industry Equilibrium.” Quarterly Journal of Economics 117, 85-120.

Grossman, Gene, and Elhanan Helpman (2005). "Outsourcing in a Global Economy." Review of Economic Studies 72, 135-159.

Hart, Oliver (1995). Firms: Contracts and Financial Structure. Oxford University Press.

Joskow, Paul (2005). "Vertical Integration." In Handbook of New Institutional Economics, edited by Claude Ménard and Many Shirley. Springer.

Klein, Peter (2005). "The Make-or-Buy Decision: Lessons from Empirical Studies.” In Handbook of New Institutional Economics, edited by Claude Ménard and Many Shirley. Springer.

Marin, Dalia, and Theirry Verdier (2003). "Globalization and the New Enterprise." Journal of the European Economic Association, Paper and Proceedings, 1(2), 337-344.

Marin, Dalia, and Theirry. Verdier (2005). "Corporate Hierarchies and International Trade: Theory and Evidence." Working Paper, PSE.

Milgrom, Paul, and John Roberts (1990). "The Economics of Modern Manufacturing: Technology, Strategy, and Organization." AER, 80, 511-528.

Oulton, Nick, and Sylaja Srinivasan (2005). "Productivity Growth in UK Industries, 1970 2000: Structural Change and the Role of ICT." Bank of England Working Paper No. 259.

van Ark, Bart, and Robert McGuckin (2001). "Making the Most of the Information Age: Productivity and Structural Reform in the New Economy." The Conference Board Conferences, R-1301-01-RR, October.

Williamson, Oliver (1996). The Mechanisms of Governance. Oxford University Press.

Wooldridge, Jeff (2002). Econometric Analysis of Cross Section and Panel Data. MIT Press. 